\title{
Küreselleşme Sürecinde Firmalar Arası Stratejik Isşbirliği
}

\author{
Orhan Çelik \\ A.Ü. Siyasal Bilgiler Fakültesi \\ Araştırma Görevlisi
}

\section{Özet}

Ortak stratejik amaçları gerçekleştirmek için iki veya daha fazla bağımsız firma tarafından gerçekleştirilen ortaklık anlaşması olarak tanımlanabilecek stratejik işbirliği, küresel rekabet koşullarında firmalar ạ̧sından daha da önem kazanmaya başlamıştır. Firmalar bir çok türde stratejik işbirliği gerçekleştirebilirler. Burada önemli olan amaca göre işbirliği türünün ve ortaơ̆ın belirlenmesidir. Stratejik işbirliği, amacın belirlenmesinden, işbirliği sonucunun değerlendirilmesine kadar uzanan bir süreçtir. Dolayısıyla bu sürecin tüm aşamalarını ayı ayrı değerlendirilmesi ve bir aşama tamamlanmadan diğer aşamaya geçilmemesi gerekir.

Galışmada bu ayrımlar ortaya konulduktan sonra stratejik işbirliğine giren firmaların karşı karşıya kaldıkları riskler, ilişki riski ve performans riski olarak incelenmiştir. Firmaların karşı karşıya kaldıkları risklerin bu şekilde sınıflandırılması işbirliği süreci sonuçlarının değerlendirilmesi bakımından önemli olmaktadır.

\section{Strategic Alliances in Globalization Process}

\section{Abstract}

Strategic alliances are agreements that two or more independent firms are intended to achieve the joint strategic purpose of these firms. In global competence conditions the strategic alliances are getting more importance. There are many kinds of strategic alliances. In strategic alliance process, determining the purpose of alliance and partner is very important. Strategic alliances is a process that continuos from determining the purpose to assessing the alliance. So all the stages of this process have to be assessed one by one and unless a stage is completed, the other stage shouldn't began.

After explaining these situations in this article, the risks that the firms are faced in strategic alliances are also considered. These risks are relational risk and performance risk. The classification of risks in this way is important in accessing the result of the strategic alliances. 


\section{Küreselleşme Sürecinde Firmalar Arası Stratejik İşbirliği}

\section{Giriş}

Küresel rekabet koşullannda stratejik işbirliği, artık bir çok firma tarafından yaygın bir şckilde uıgulanmaktadır. Günümüzde özellikle küresel rekabetin yoğun bir şckilde yaşandığ y yüksck teknoloji gerektiren sektörlerde stratejik işbirliği daha sık bir şekilde gerçekleştirilmektedir.

Günümüz koşullarında düşünüldüğünde stratejik işbirliğinin, firmaların tüm fonksiyonlarının yeniden tanımlanmasının gerekli olduğu küresel rekabet koşullarında değerlendirilmesi bir zorunluluk olmaktadır. Çünkü firmaların diğer faaliyetlerinde olduğu gibi stratejik işbirliği faaliyetlerinde de geçmişe göre günümüzde önemli değişimler görülmektedir.

Çalışmamızda küresel rekabet koşullarında firmalar arası stratejik işbirliği tartışlırken bu noktalar ortaya konulmaya çalışılmıştır. Bunun yanında stratejik işbirliğinin firmalar açısından bir süreç olarak görülmesi ve bağlı olarak da sürecin tanımlanması gerektiği için işbirliği süreci ayrıntılı olarak incelenmiştir.

\section{Küreselleşme ve Firmalar Arası Stratejik İşbirliği ${ }^{1}$}

Ülkelerarası mal, sermaye ve işgücü hareketlerinin giderek serbestleşmesi süreci biçiminde gerçekleşen küreselleşme sonucu dünyanın giderek küçüldüğü herkeş̧e kabul edilen ortak bir görüştür. Avrupa, $A B D$ ve Japonya gibi gelişmiş ülkelerin ekonomileri, 1960'lardan bu yana ticaret ve sermaye akışlan nedeniyle önemli ölçüde birbirine bağlanmıştır. Küresclleşme olarak tanımlanan bugünkü dönemin en önemli yeniliği dünyanın daha fakir bölgelerinin küresel ticaret, finans ve üretim sistemlerine, sömürge bağımlılığından çok birer ortak ve taraf olarak yer almalarını sağlamasıdır. Dünya ekonomisi için bir yenilik olarak

1 Ingilizcedeki "strategic alliances" karşılı̆ğ olarak Türkçe literatürde "stratejik ittifaklar" kavramı da kullanılmaktadır. Ancak çalışmamızda, Türkçe literatüre artık yerleşmiş olduğunu düşündüğümüz "stratejik işbirliği" kavramı strategic alliances kavramının karsılığı olarak kullanılmışır. 
tanımlanabilecek küresel rekabet koşullarının tüm ulusal ekonomileri etkilemesini, ülkeler arasında iletişimin ve ulaştırmanın hızlı ve ucuz hale gelmesi artırmıştır. Günümüz teknolojik gelişmelerinin bir sonucu olarak ifade edilebilecek bu durumun etkilerini gelecekte de sürdüreceği tahmin edilmektedir.

Küreselleşmenin etkisi ile ulusal ekonomiler belli başlı dört alanda birbirleriyle entegre hale gelmiştir. Bu alanlar şunlardır:

- Ticaret

- Sermaye hareketleri

- Üretim

- Anlaşmalar ve kurumlar ${ }^{2}$

Küreselleşme sürecinin, en az makro etkileri kadar işletme faaliyetleri üzerinde de etkisi olmaktadır. Küreselleşme ile dünyanın giderek küçülmesi, ulusal sınırlar içinde faaliyet gösteren işletmelerin dünya çapında faaliyet gösterebilmelerini daha kolay hale getirmiştir. Artık işletmeler, ulusal pazarlar yerine tüm dünyayı pazar olarak görmektedirler. Bunun yanı sıra iletişimin ve ulaşımın daha ucuz ve hızlı hale gelmesi, dünya üzerindeki farklı kültürleri harmanlamış böylece işletmelerin ürettikleri ürünlerin uluslararası pazarlarda satılabilmesi ve tüm dünya çapında tanman ürünler olması önündeki engeller de ortadan kalkmaya başlamıştır.

Şekil 1'de 1950 yılından bu yana dünya ihracatının gelişimi ortaya konulmuştur. Buna göre; özellikle 1970'li yıllarda başlayan hızlı artı̧ eğilimi günümüzde de sürmektedir. (Nelson, 1994: 6). Buradan da açık bir şekilde görülebileceği gibi, dünya ticaretinde görülen gelişme hızlı bir yükselme eğilimi içindedir. Bu gelişme sadece mal ve hizmet hareketlerinde değil, sermaye hareketlerinde de görülmcktedir.

Firmalarm uluslararası pazarlarda faaliyet göstermeleri dolayısıyla küresel rekabet koşullarına ayak uydurabilmeleri için yeni ürünler geliştirmeleri ve yeni teknolojiler yaratmaları gerekmektedir. Küresel rekabetin sonucu olarak artık firmaların faaliyet alanları sürekli değişme ve genişlemektedir. Bu durum, firmalar açısından daha karmaşıklaşan işletme amaçlannı gerçekleştirmeye yönelik yeni stratejilerin belirlenmesini gerektirir. Firmalar giderek karmaşıklaşan koşullarda ayakta kalabilmek için yeni yapılanmalara gitmek zorundadırlar.

2 Günümüzde ülkeler arasında yoğun bir inlaşma ve kurumlar ağı bulunmaktadır. Küreselleşme sürecinin sonucu olarak ülkelerarasında ticaret, yatırım ve vergi politikaları, sermaye hareketleri, gümrük tarifeleri, fikri mülkiyet hakları, banka denetimi, uluslararası rekabet, rüşvetin önlenmesi gibi bir çok konuya ilişkin uluslararası anlaşma ve uluslararası kurum ciddi biçimde artış göstermiş̧tir. Bunun sonucu olarak artan uluslararası anlaşmalar, cok tarafl yükümlülükler, bölgesel yükümlülükler ve iki taraflı yükümlülükler yoluyla ülkeleri birbirine daha fazla bağlamaktadır. 


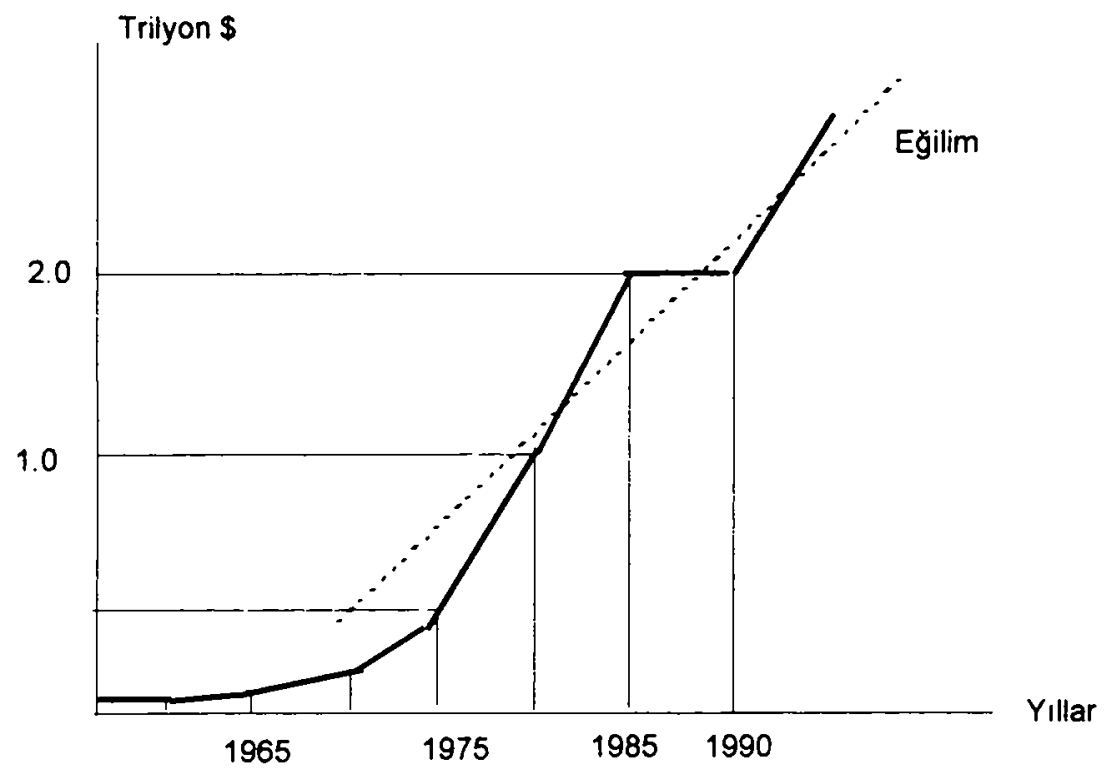

Sekil 1: Dünya Ihracatı

Kaynak: Nelson, s. 6.

Genel olarak ortaya konulan bu eğilimler, firmaların artık tek başlarına uluslararası pazarlara girmelerinin daha kolay olduğu anlamına gelir. Oysa dünya üzerindeki eğilime bakıldığında durumun bu yönde olmadığı görülmektedir (Ward, 1995: 215). Firmaların küreselleşmenin getirdiği olanaklara karşın artık daha fazla birlikte hareket etme veya yeni pazarlara birlikte girme eğiliminde oldukları da sıklıkla görülmektedir.

Küreselleşmenin sonucu olarak bu eğilimler yaşanırken, dünya ekonomisinde yaşanan bir diğer eğilim de dünyanın ana ticaret bölgelerine ayrılmasıdır. Ana ticaret bölgeleri, bu bölgelerin dışında faaliyet gösteren firmalara bir takım giriş engelleri yaratmaktadır. Bu anlamda firmaların birbirleriyle işbirliği içinde olmaları bu ticaret bölgelerinin "içinde" olma arayışında olan birçok firma için önemli hale gelmiştir. Çünkü, bu ticaret bölgelerinin firma faaliyetleri açısından en önemli etkilerinden biri rekabet politikalarının oluşmasında kendi düzenleyici organlannın belirleyici rol oynamasıdır. (Ward, 1995: 219). Bu durumda dışarıdaki firmalar "içeridekiler" statüsünü kazanabilmek için içerideki bir firma ile işbirliğine gitmek veya birleşmek gibi yolları seçebilecektir. 
Küreselleşmenin sonucu olarak ortaya çıkan bu gelişmeler yeni işletmecilik anlayışının doğmasına neden olmuştur. Bu yeni anlayıs sonucu olarak firmalar, artık uluslararası alanlarda faaliyet gösterebilmek için küresel rekabet koşullarına ayak uydurmalıdırlar. (Nelson, 1994: 9). Yeni işletmecilik anlayışı sadece ulusal pazarda faaliyet gösteren firmalar açısından değil, uluslararası pazarlarda faaliyet gösteren firmalar açısından da rekabet avantajlan ve bilgi transferi gibi uluslararası işletmecilik kavramlannı yeniden tanımlama gereğini ortaya koymuştur.

Küresel rekabet koşullarma ayak uydurabilmek için firmalarnn, artık örgüt yapılanndan personel politikalarına, finansman politikalarından üretim tekniklerine kadar bir çok değişimi gerçekleştirmesi gerekir. Firmalar arası stratejik işbirliği, firmaların bu değişimi gerçekleştirmede ve dolayısıyla küresel rekabete ayak uydurabilmesinde kullandıkları önemli bir yol olarak karşımıza çıkmaktadır.

Yeni işletmecilik anlayışının diğer sonucu olarak artık firmalar, faaliyetlerini sürdürebilmek için gerckirse rakipleriyle bile işbirliği yapmaktadırlar. (Hamel, Doz ve Prahalad, 1989: 133).

\section{Firmalar Arası Stratejik İşbirliği Süreci}

Stratejik işbirliği ${ }^{3}$, ortak stratejik amaçlarını gerçekleştirmek için iki veya daha fazla bağımsız firma tarafından yapılan ortaklık anlaşması olarak tanımlanabilir. Burada önemli olan nokta, firmaların birlikte gerçekleştirmek istedikleri amaçların stratejik nitelik taşımasıdır. Amaçların stratejik olması ise uzun vadeli amaçlar olması anlamına gelir. Stratejik işbirliği, genellikle tek bir firma için çok yüksek maliyet gerektiren veya tamamlayıcı teknolojiye gereksinim duyan faaliyetlerin gerçekleştirilmesi arayışında olan firmalar tarafından gerçekleştirilir. (Koch, 1995: 354). Buna göre firmalar arası stratejik işbirliğinin belirleyici özellikleri şu şekilde özetlenebilir: (Khemani ve Waverman, 1997: 127).

i. Ortak bir amaca ulaşmak isteyen firmaların aralannda yaptıkları anlaşma çerçevesinde oluşan iki veya daha çok taraflı bir ilişkidir.

3 Işletme literatüründe stratejinin kelime kökeninin iki kaynağa dayandığı belirtilmektedir. Bu kaynaklardan biri; Latince yol, çizgi veya yatak anlamına gelen stratum kavramı, diğeri ise eski Yunanlı General Strategos'un adidır. bu anlamada strateji, generalin savas sanatını ve bilgisini ifade etmektedir. Işletme literatüründe strateji, işletmenin çeşitli fonksiyonlan arasında meydana gelen karısıklıkları açıklığa kavuşturan ve genel amaçlan belirleyen, işletmenin amaçlannı gerçekleştirebilmesi ile ilgili seçime dayalı kararlar bütünü olarak tanmlanmaktadır. Diğer bir deyişle strateji, amaçlara ulaşmak için eldeki kaynakları en iyi şekilde kullanarak uzun süreli genel bir işletme planı yapmak şeklinde tanımlanaabilir. Bu açıdan bakıldığında strateji, işletmenin devamlı olarak tekrarlanan işlerin tersine uzun vadeli amaçların gerçekleştirmek için başvurdugu yollan ifade eder. 
ii. Firmaların birlikte hareket etmelerinin ana nedeni, ortak bir stratejik amacı gerçekleştirmektir.

iii. Stratejik işbirliği hisse senedi değişimini de içerebilir. Ancak, burada hisse senedi değişimi kontrol amacı taşımaz. Bu açıdan bakıldığında, stratejik işbirliği, şirket birleşmelerinden önemli farklılıklar gösterir.

Birleşmeler iki veya daha fazla firmanın yeni bir firma kurarak bir araya gelmeleri (merger) veya bir firmanın diğer bir firmayı tüm aktif ve pasifleriyle devralması yoluyla (acquisition) gerçekleştirilebilir. (Green, 1990: 19). Hem yeni bir firma kurulması yoluyla birleşmede, hem de devralma yoluyla birleşmede firmalardan en az birinin tüzel kişiliği ortadan kalkmaktadır. Stratejik işbirliğinde ise, firmalarm tüzel kişiliklerini kaybetmesi sözkonusu değildir.

Stratejik işbirliği firmalar açısından yeni bir kavram değildir. Yıllardır özellikle uluslararası pazarlarda faaliyet gösteren çok uluslu firmalar tarafından sıklıkla kullanılmıştır. Küreselleşme sonucu ortaya çıkan küresel rekabet koşullarına ayak uydurmak isteyen günümüz firmalarının bir araç olarak tekrar stratejik işbirliğini sıklıkla kullanmaya başlamalan stratejik işbirliğini yeniden önemli hale getirmiştir. Stratejik işbirliği özellikle 20. yüzyılın başlarında uluslararası işletme faaliyetlerinde önemli bir yer tutmuştur. Bu yıllarda firmalar arası stratejik işbirliği özellikle doğal kaynaklann elde edilmesi ve kullanılmasında temel bir araç olarak kullanılmıştır. (Mowery, Oxley ve Silverman, 1996: 78). Ancak, günümüzde stratejik işbirliği daha çok teknoloji yoğun sektörlerde sıkça karşılaşılmaktadır. Bu durum, stratejik işbirliğinin yapılma nedenlerinin değişmesi anlamına gelir. Firmalar arası stratejik işbirliği faaliyetlerinin türleri özellikle son yirmi yılda önemli ölçüde artmıştır. Örneğin ortak ar-ge faaliyetleri (joint $R \& D$ ) ve ortak ürün geliştirme faaliyetleri firmalar arasında teknoloji transferini ve bilgi değişimini artırmıştır. (Mowery, Oxley ve Silverman, 1996: 79).

Firmalar arasında gerçekleştirilen stratejik işbirliği faaliyetlerinde görülen önemli bir gelişme de rakip firmaların arasında da işbirliğinin görülmesidir. Bir paradoks olarak kabul edilebilecek bu durum, küreselleşme sürecinin kaçınılmaz bir sonucu olarak ortaya çıkmaktadır. Bu tür stratejik işbirliğinde rakip firmalar hiçbir zaman rakip olduklarını unutmazlar yani silahlarını bırakmazlar. Burada amaç her iki taraf için de avantaj sağlayacak ortak bir amaca daha kolay ulaşmaktır. (Hamel, Doz ve Prahaland, 1989: 133). Bu durumdaki firmalar rekabetçi uzlaşma konumlanın koruyarak ortak bir stratejik amaca ulaşmaya çalışırlar. Rakip işletmelerin aralarında yaptıkları bu işbirliği de diğer jşbirliklerinde olduğu gibi karşılıklı fayda sağlama amacına dayanır (Müftüoğlu, 1997: 244). 


\section{Stratejik İşbirliği Türleri}

Firmalar arasında stratejik işbirliği çeşitli şekillerde gerçekleşebilir. Bunlar şu şekilde sıralanabilir: (Das Ve Teng, 1996: 827).

- Direkt yatırımlar,

- Ortak girişimler (joint ventures),

- Arz- talep edici ilişkisi,

- Teknoloji lisans sözleşmeleri,

- Ar-ge anlaşmaları.

Çeşitli şekillerde ortaya çıkan firmalar arası stratejik işbirliği genel olarak şu şekilde sınıflandırılabilir:

- Yatay stratejik işbirliği

- Dikey stratejik işbirliği

- Karma stratejik işbirliği

\section{a. Yatay (Horizantal) Stratejik İ̧̧birliği}

Aynı alanda faaliyet gösteren firmaların aralannda yaptıkları stratejik işbirliğidir. Bu tür stratejik işbirliği günümüzde özellikle ar-ge faalietlerinde çok daha fazla ölçüde karşımıza çıkmaktadır. Ortak ar-ge faaliıtlerinde bulunma veya ar-ge faaliyeti sonucunda elde edilmiş yeni bir ürünün ticari hale getirilmesi aşamalarında sıkça bu tür stratejik işbirliğinin yapıldığı görülmektedir. (Khemani ve Waverman, 1997: 134).

Firmalann yatay stratcjik işbirliğine gitmelerinin birçok nedeni olabilir. Bunlardan en önemlileri ölçek ckonomilerinden yararlanmak, giriş engellerini aşmak, riski azaltmak ve bilgi transferi sağlamak şeklinde sıralanabilir.

\section{b. Dikey (Vertical) Stratejik İş̧irliği}

Dikey stratejik işbirliği, herhangi bir malın veya hizmetin üretiminden satışına kadar farklı aşamalarında faaliyette bulunan firmalar arasında yapılan stratejik işbirliğidir.

Firmalann dikey stratejik işbirliğine gitmelerinin al tında yatan nedenlerden en önemlileri, tedarik bağımlılığından kurtulmalarının sağlanması, pazarlama olanaklarının arttırılması isteğidir. (Khemany ve Waverman, 1997: 135).

\section{c. Karma (Conglomerate) Stratejik işbirliği}

Karma stratejik işbirliği, birbirleriyle ilişkisiz alanlarda faaliyet gösteren 
firmalar arasında gerçekleştirilen stratejik işbirliği türüdür. Bu tür işbirliği, sıklıkla sabit teknolojili, farklı endüstrilerde mal ve hizmetlerin üretimini yapan firmalar arasında gerçekleştirilir.

Yukarıda belirtilen sinıflandırmanın yanı sıra firmalar arası stratejik işbirliği alternatif olarak şu şekilde de sınıflandınlabilir: (DAS ve TENG, 1996: 827).

- Hisse senedi değişimini öngören stratejik işbirliği,

- Hisse senedi değişimini öngörmeyen stratejik işbirliği.

Hisse senedi değişimini öngören stratejik işbirliği, yeni hisse senedi sahipliği yaratan stratejik işbirliği şekli olarak da ifade edilebilir. Bu tür stratejik işbirliği iki temel şekilde gerçekleştirilebilir: (DAS ve TENG, 1996: 828).

i. Doğrudan yatırımlar,

ii. Ortak girişimler.

Doğrudan yatırımlar, bir firmanın diğer firma veya firmaların hisse senetlerinin bir kısmını alması yoluyla gerçekleştirilen stratejik işbirliğidir. Ortak girişimlerde ise belli bir amaca ulaşabilmek için bağımsız iki veya daha fazla firmanin yeni bir firmanin hisse senetlerini elde etmeleri yoluyla gerçckleştirilir.

\section{B. Firmaların Stratejik İşbirliği Yapma Nedenleri}

Firmalann stratejik işbirliği yapmasının altında yatan temel neden, firmaların karşı karşıya oldukları diğer alternatiflerle gerçekleştirilmesi mümkün olmayan veya ekonomik olmayan stratejik amaçların gerçekleştirilmesi şeklinde ifade edilebilir.

Şekil 2'de de belirtildiği gibi firmaların gerçekleştirdikleri stratejik işbirliği, savunma ve saldırgan rekabet stratejileri olarak iki uç konum arasında yer alır. (Newman ve Chaharbaghi, 1996: 851).

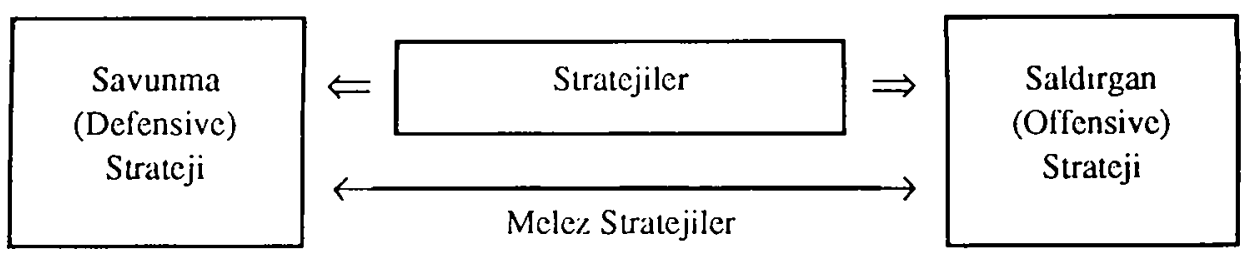

Sekil 2: Stratejik Işbirliğinde Stratejik Amaçlar

Kaynak: Newman ve Chaharbaghi, s. 851. 
Savunma stratejisinde firma, çoğunlukla varolan bir kapasiteyi ve pazar payını korumayı amaç edinmektedir. Saldırgan strateji ise, özellikle hızlı değişen pazarlarda gerçekleştirilmektedir ve firmaların pazar payını artırmaya yönelik stratejiler olarak tanımlanabilmektedir.

Firmaların stratejik işbirliğine gitmelerinin altında yatan nedenler çok çeşitlidir. Özellikle yüksek ar-ge harcamaları yapılmasının zorunlu olduğu teknoloji yoğun sektörlerde faaliyet gösteren firmalar arasında stratejik işbirliğinin çok yaygın biçimde gerçekleştirilmesi, stratejik işbirliği nedenlerini günümüzde farklılaştırmıştır. (Murray ve Mahon, 1993: 105). Firmalann stratejik işbirliği yapma nedenlerinden en önemlilerinden biri örgütsel yapılarından kaynaklanan nedenler olarak ifade edilebilir.

Stratejik işbirliğine gidilmesinde, firmaların örgütsel yapılarından kaynaklanan nedenler beş ana grupta toplanabilir.

1. Firmaların faaliyetini sürdürmek için teknoloji veya üretim kapasitesi sağlamak

Firmalann stratejik işbirliği yapmalarının önemli bir nedeni firmaların yeni teknolojiler elde etmek isteğidir. Yüksek ar-ge maliyeti ve riski, ürünlerin yaşam sürelerinin kısalmasının yoğun olduğu sektörlerde teknoloji transferi ve gerekli üretim kapasitesini sağlamak daha önemli olmaktadır. (Mowery, Oxley ve Silverman, 1996: 793) Firmaların yeni pazarlara, ürünlere ve teknolojilere geçmelerinde bilgi transferi ve değişimi hayatta kalmalan için kritik önem taşımaktadır. (Wathne, Ross ve Krogh, 1996: 55) Yeni teknolojiler elde etmek özellikle firmalarm ar-ge faaliyetlerinde işbirliğine gitmeleri yoluyla sağlanmaktadır. Bu gün artık firmalar adı geçen gerekliliğin bir sonucu olarak, ar-ge faaliyetlerini dünya ölçeğinde sürdürmektedirler. (Kuemmerle, 1997: 61).

2. Yeni Pazarlara Girme

Özellikle giriş engellerinin bulunduğu pazarlara girmenin yollarından biri de bu pazarda faaliyet gösteren bir başka firma ile stratejik işbirliğine gitmektir.

\section{Finansal Riski Düşürmek}

Bazı alanlarda firmaların faaliyet göstermeleri veya faaliyetlerini sürdürmeleri büyük ölçüde finansal riskle karşılaşmalannı gerektirir. Firmalar bu durumda stratejik işbirliği yoluyla bu riski düşürmeıe çalışırlar. (Murray ve Mohan, 1993: 106).

\section{4. Ülke Riskini Düşürmek}

Firmalar bazen, politik istikrara sahip olmayan yabancı bir ülkede yatırım yapmayı düşünebilir. Böyle bir ülkeye yatırım yapmak firmanın önceden tahmin edilmesi son derece gụ̧̈ bir takım riskleri de üstlenmesini gerektirir. Bu 
durumda, firma riski düşürmek için stratejik işbirliğine gitme yolunu seçebilecektir. (Murray ve Mohan, 1993: 106)

5. Rekabet Gücünü Arttırma veya Rekabet Eşitliği Sağlamak

Firma, stratejik işbirliğine giderek pazarda kendi aleyhine olan rekabet koşullarını dengeleycbilir vcya hakim duruma geçerek rakiplerinden daha avantajlı konuma geçebilir. (Murray ve Mohan, 1993: 106).

Belirtilen bu nedenlerden farklı olarak, stratejik işbirliğine gidilmesinde firmaların kendi örgütsel yapısından değil, çevresel koşullardan kaynaklanan nedenler de söz konusudur. Ekonomik ve politik belirsizlik, hızlı teknolojik gelişmelerin yaşandiğı sektörlerde faaliyet gösterme ve devlet teşviki ve korumacılığı çevresel koşullardan kaynaklanan nedenlerin ilk akla gelenleri olarak siralanabilir.

Burada dikkatle üzerinde durulması gereken bir önemli nokta da, belirtilen nedenlerin birbirinden bağımsız olmamasıdır. Bir stratejik işbirliği, aynı anda birçok nedeni gözönünde bulundurarak gerçekleştirilebilir.

\section{Stratejik İşbirliğinde Karar Süreci}

Stratejik işbirliğinde karar süreci beş ana aşamaya ayrılarak incelenebilir. Bu aşamalar şunlardır: (Brouthers, Brouthers ve Harris, 1997: 40).

1. Bir pazara giriş yönteminin seçilmesi veya stratejik işbirliğinin pazarda faaliyet göstermenin en iyi yolu olup olmadığının belirlenmesi kararı,

2. Potansiyel ortaklarm belirlenmesi kararı,

3. Potansiyel ortaklarla stratejik işbirliği görüşmelerinin yapılması kararı,

4. Stratejik işbirliğinin sürdürülmesi kararı,

5. Stratejik işbirliğinin değerlendirilmesi.

Sürecin beş karar aşaması Şekil 3'te özet bir şekilde ifade edilmiştir. Stratejik işbirliği yapmak isteyen firmalar, her bir karar aşamasını tamamlayarak diğer aşamaya geçeccklerdir.

Bu açıdan bakıldığında her bir aşamada diğer bir aşamaya geçip geçmeme kararının verilmesini gerekir.

Firmalarm stratejik işbirliği yapmalarında izlenecek karar süreci yukarıdaki gibi almaları gereken kararlar şeklinde özetlenmesine karşın, stratejik işbirliğinin aşamaları aşağıdaki gibi sıralanabilir:

i. Hazırlık aşaması,

ii. Cörüşme aşaması, 
Orhan Çelik • Küreselleşme Sürecinde Firmalar Arası Stratejik Işbirliği • 33
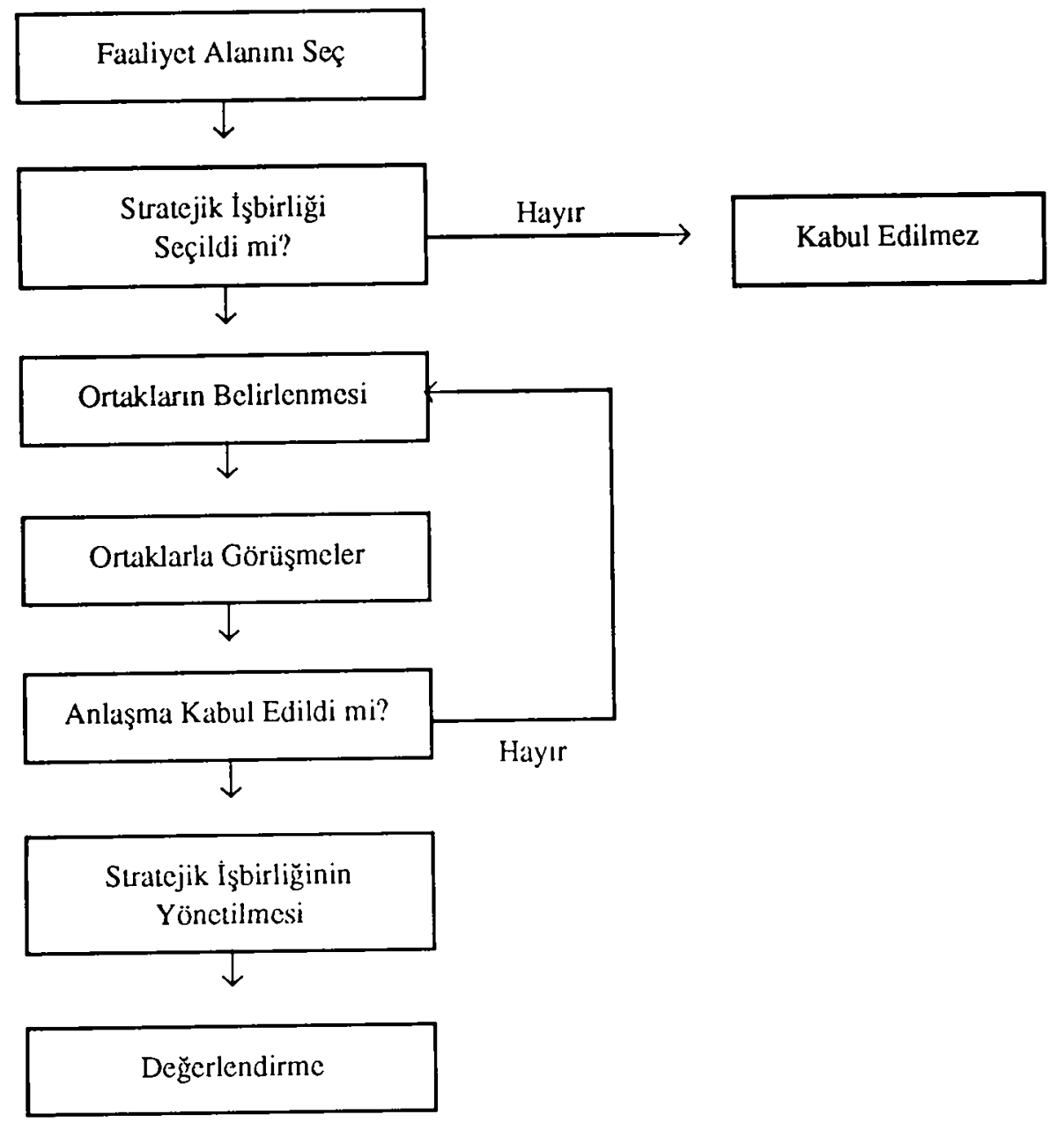

Sekil 3: Stratejik Işbirliği Karar Modeli

Kaynak: Brouthers, Brouthers ve Harris, s. 40.

iii. Başlangıç aşaması,

iv. Sürdürme aşaması,

v. Bitiş aşaması. (Murray ve Mohan, 1993: 109)

Firmaların, faaliyet alanı olarak stratejik işbirliğini seçmesi hazırlık aşaması olarak kabul edilir. Hazırlık aşamasında firmalar, iki önemli unsurla karşılaşırlar. Bunlar şu şekilde ifade edilebilir: 
1. Firma ile ilişkisi olan taraflann stratejik işbirliği düşüncesini desteklemesi,

2. Stratejik işbirliği karan verilmesi durumunda, her iki taraf için kazanç sağlayacak stratejik uyumun ortaya konulmasıdır. (Chakravarthy ve Lorange, 1991: 219).

Hazırlık aşamasında, stratejik işbirliği faaliyetinin şirketle ilişkisi olan her kesim için kabul edilebilir olup olmadığı belirlenir. Bu açıdan bakıldığında, hazırlık aşamasında tarafların üst yönetimlerinin işbirliğine bakışı ve ortakların durumu aşamanın tamamlanması için önemli olmaktadır. Bu aşamada, firmalarla ilişkili taraflarnn, kararları derinlemesine değerlendirmeleri gerekir.

Hazırlık aşamasında karşılaşılan ikinci unsur da stratejik işbirliği yapmak isteyen firmaların stratejik uyumun sağlanmasıdır. Bu aşamada stratejik amaca ulaşmayı sağlayacak ortakların seçimi yapılmaktadır. İdeal stratejik işbirliği anlaşmalarında ortakların tamamlayıcı kaynaklara ve ortak amaçlara sahip olmaları sağlanmalıdır. (Das ve Teng, 1997: 54).

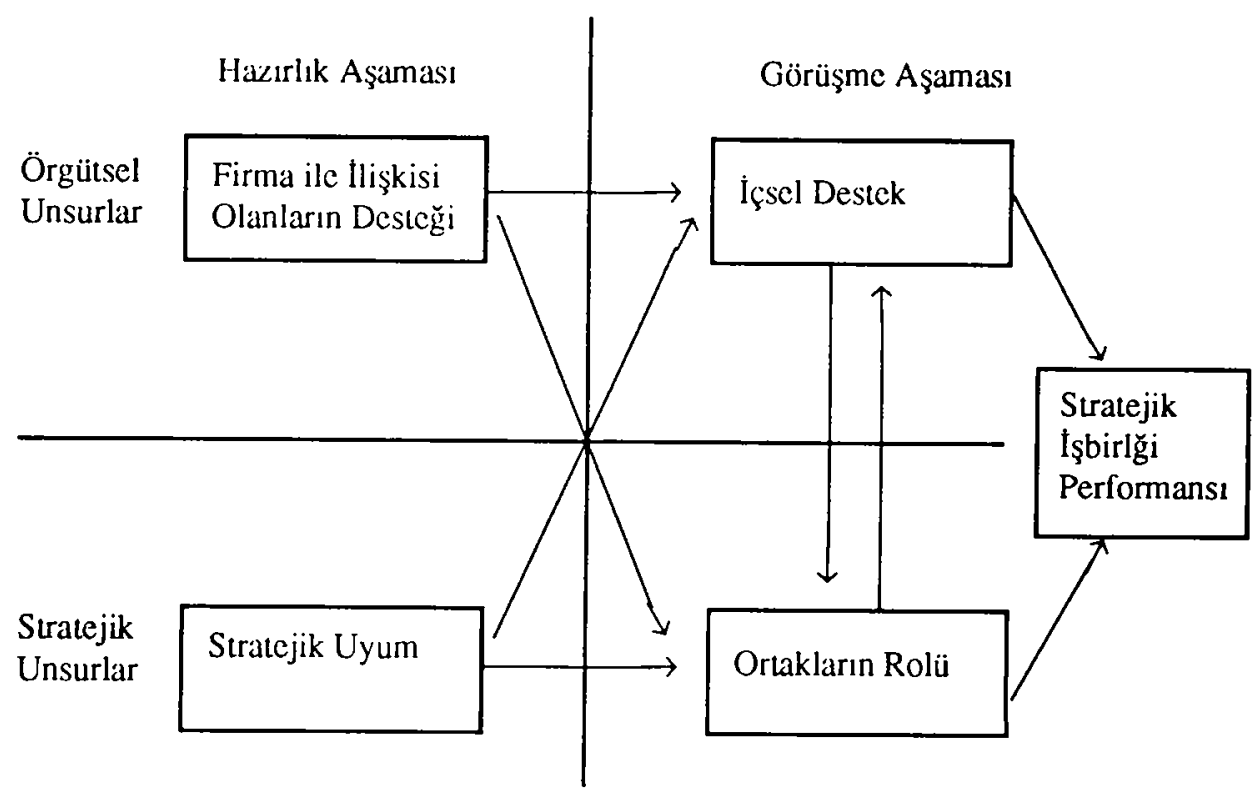

Sekil 4: Stratejik Işbirliğinde Hazırlik ve Cörüşme Aşamalan

Kaynak. Chakravorty ve Lorange, s. 219.

Stratejik işbirliğinin ikinci aşaması görüşme aşamasıdır. Görüşme aşamasında firmalar iki durumla karşı karşıyadırlar. Bunlardan ilki, her firma 
için stratejik işbirliğine gitme durumunda içsel unsurların test edilmesidir. Yani ne tür stratejik işbirliğine girilirse ortak amaca ulaşmak daha kolay olacaktır sorusunun yanıtlanması gerekir. Bunun dışında firmanın içsel yapısının çeşitli alternatif stratejik işbirliği faaliıetlerini nasıl etkileneceğinin belirlenmesi de gerekir. Diğer unsur ise stratejik işbirliği için başlangıç planının hazırlanmasıdır. Başlangıৎ planının hazırlanması şu kararlann verilmesini gerektirir:

1. Her iki firmanın da kazanç elde etmesi için stratejik işbirliğinin yapısı nasıl olmalıdır?

2. Belirlenen stratejik işbirliğinde ortakların yasal yükümlülükleri neler olacaktır?

3. Ortakların finansal yükümlülükleri neler olacaktır?

Kısaca bu aşamada taraflar işbirliği sözleşmesi yapmak için ayrıntılı görüşmeler yaparlar. Eğer görüşme aşaması başarıyla tamamlanırsa başlangıৎ aşamasına geçilir. Artık bu aşamada taraflar ortak amaç için ortak faaliyette bulunmaya başlarlar.

Başlangıৎ aşamasından sonra sürdürme aşamasına geçilir. Başlangıৎ̧ aşaması sonuçları değerlendirildiğinde her iki taraf için kazanç sağlanıyorsa sürdürme aşaması ile ilişkiye devam edilir. Eğer başlangıç ve sürdürme aşamalannda başarısızlıkla karşılaşılırsa bitiş aşamasına geçilir. Şekil 5 'de de belirtildiği gibi bu aşamalar birbirini izleyen aşamalardır.

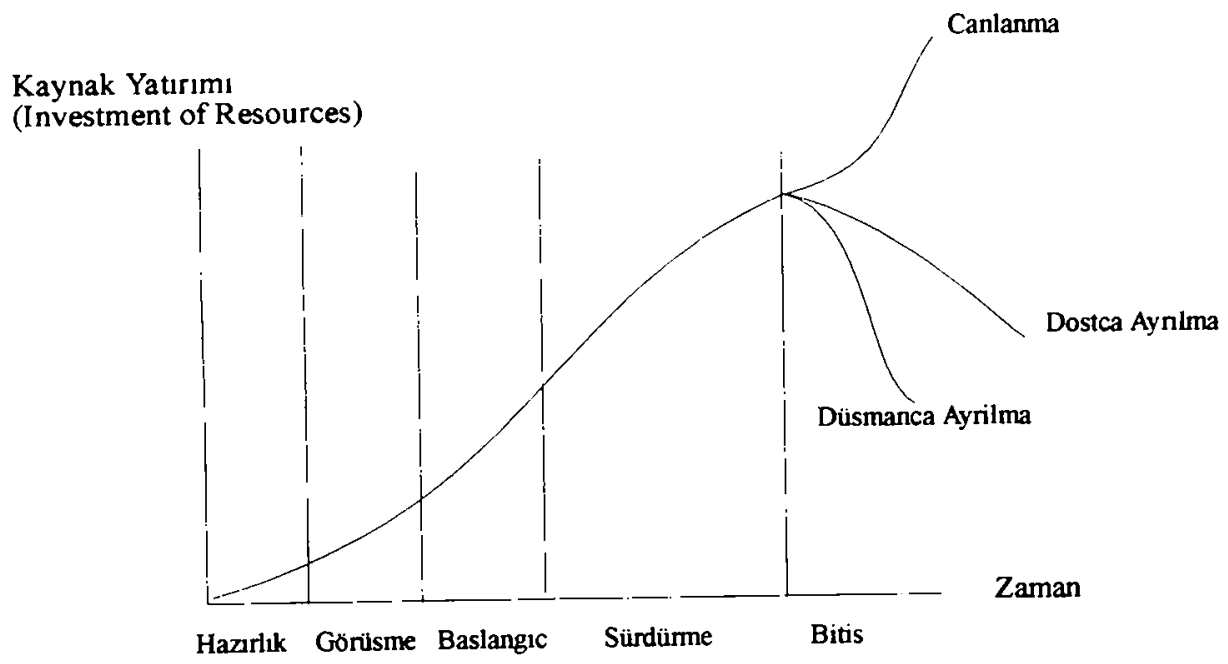

Şekil 5: Stratejik Işbirliği Yaşam Ĕ̆risi

Kaynak: Murray ve Mahon, s. 109. 
Bitiş aşaması, stratcjik işbirliği faaliyetinin geleceği için son derece önemlidir. Bitiş aşamasında üç olası durum söz konusu olmaktadır. Bunlar şu şekilde sıralanabilir. (Murray ve Mohan, 1993: 110)

1. Canlanma,

2. Dostça ayrilma,

3. Düşmanca ayrılma.

Bitiş aşamasının bir türü canlanmadır. Ortaklar bu durumda diğer alanlarda işbirliğine gitmek üzere bu faaliyet alanındaki stratejik işbirliğini bitirirler. Yeni bir alanda stratejik işbirliğine gitme karan vermeleri ya yaptıkları işbirliğinin başarıyla bitmesi veya stratejik işbirliğinin kendi çabalarından bağımsız olarak başarısızlıkla bitmesinden kaynaklanacaktır.

Dostça ayrılmada ise, ortaklar stratejik işbirliğinden beklenen faydaları elde edememişlerdir ve bu yolla işbirliğini sürdürmemeye karar verirler. Ancak şu aşamada başka bir işbirliğine gitmeyi de düşünmemektedirler.

Düşmanca ayrılmada ise ortaklar arasında ciddi anlaşmazlıklar söz konusudur. Bu anlamda ortak amaçların gerçekleştirilebilmesi artık mümkün görülmemektedir.

Açılamalardan da görülebileceği gibi, firmalann stratejik işbirliğini sürdürmeleri, hazırlık aşamasında ortaya konulan amaçlara ulaşmalarına bağlıdır. Firmaların ortak amaca ulaşıp ulaşamadıklanının ise her aşamada değerlendirilmesi gerekir. Bu açıdan bakıldığında, stratejik işbirliğinin değerlemesinin son derece önemli olduğu karşımıza çıkmaktadır. Ancak, unutulmaması gereken bir nokta da, değerlemenin hangi ölçüt veya ölçütlere göre yapılacağının belirlenmesi gereğidir.

Firma performansının değerlendirilmesinde, kullanılacak ölçütlerin belirlenmesi sorunu, stratejik işbirliğinde de karşımıza çımaktadır. Stratejik işbirliğinde performans ölçütü olarak etkinlik mi, kâr mı, kârlılık mı, pazar payı $\mathrm{mu}$, tüketici tatmini mi, ürün kalitesi mi kullanılacaktır. Bu ölçütlerden hangisinin kullanılacağının belirlenmesinin güç olmasının nedenlerinden ilki, bu ölçütlerin firmaların uzun vadeli performanslannı ölçmekte yetersiz kalabilmeleri, diğeri de bir çok stratejik işbirliğinde amaçların kolay bir şekilde belirlenememesinden kaynaklanmaktadır. (Stafford, 1994: 72).

Sıralanan güçlükler gözönünde bulundurularak, stratejik işbirliği performansı değerlendirilerek, faaliyeti sürdürüp sürdürmeme karanı verilmclidir. Şckil 6'da da görülebileceği gibi, değerlendirme sonuçlar geriye doğru aşamaların ve verilen kararların tek tek değerlendirilmesini içerir. 
Orhan Çəlik • Küreselleşme Sürecinde Firmalar Arası Stratejik Işbirliẓ̌i • 37

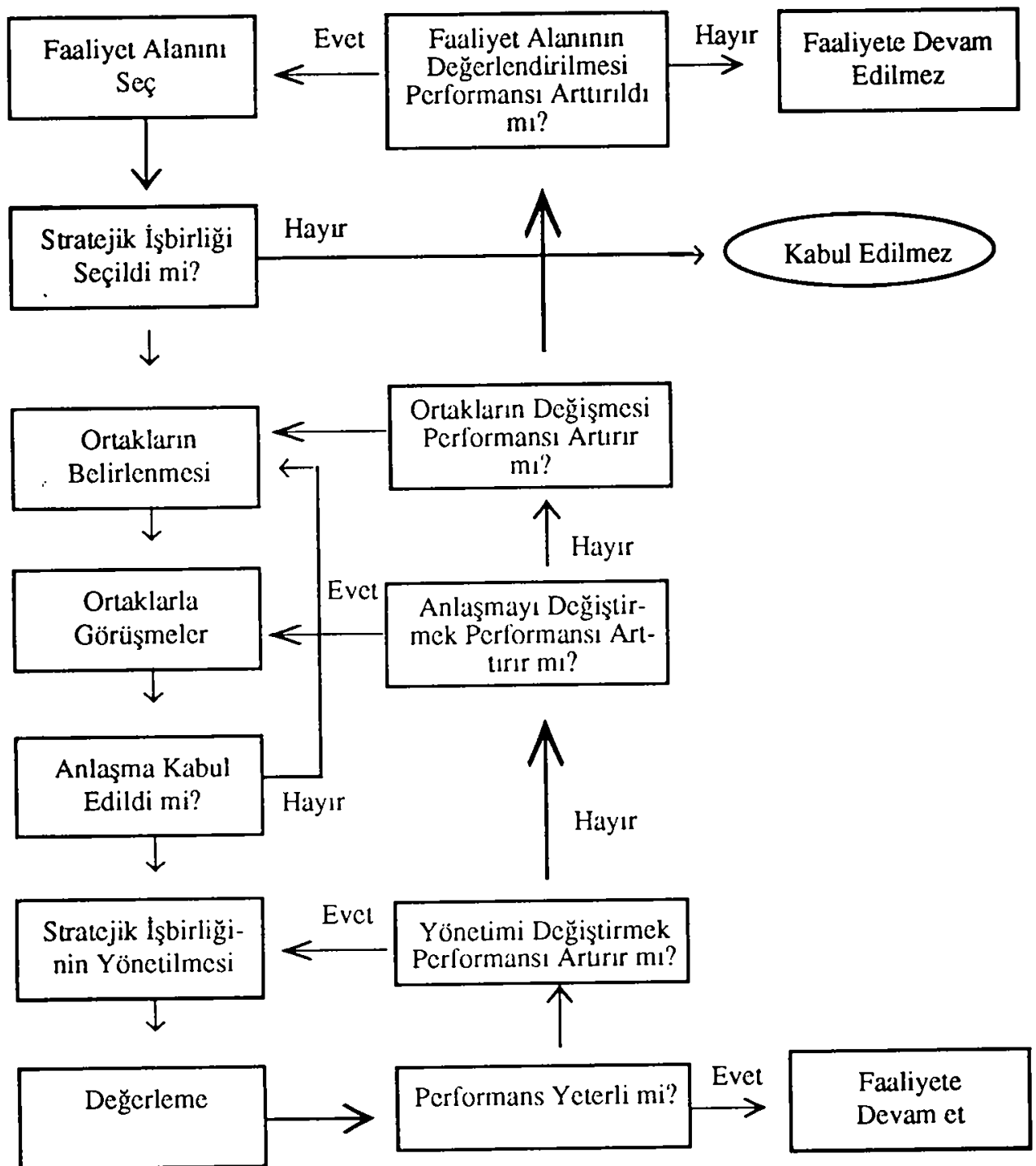

Şekil 6: Stratejik Işbirliğinde Performans Değerlemesi

Kaynak: Brouthers, Brouthers ve Harris, s. 45.

\section{Stratejik İşbirliğinde Risk}

Stratejik işbirliğinin başarıyla sürdürülebilmesi için birbirinden bağımsız ve eşit oranda performansı etkileyen iki unsur söz konusudur. Bunlar: 
1. Firmaların stratejik işbirliği ilişkisinde birbirleriyle olan ilişkisi,

2. Stratejik işbirliğinin ortak amaca ulaşmadaki performansının düzeyidir.

Bu iki etki, stratejik işbirliği faaliyetinde yer alan iki farklı risk unsurunu içermektedir. Buna göre, firmalann birbirleriyle olan ilişkilerinden kaynaklanan belirsizlik ilişki riski (relational risk) olarak tanımlanabilir.

İlişki riski, stratejik işbirliğine giren ortakların ortak amaçlara ulaşmak için kendi aralarında yaptıklan anlaşmaya uymama olasılığı olarak ifade edilebilir. (Das ve Teng, 1996: 831). Diğer bir deyişle, ortaklann kendi çıkarlarını stratejik işbirliği çıkarlarının üstünde tutmalan riskidir. Bu şekilde firmalar fırsatçı davranarak kendi çıkarlarını diğer ortakların çıkarlannı dikkate almadan maksimize etmeye çalışmaktadırlar.

Diğer bir risk ise performans riskidir. Stratejik işbirliğinin ortak amaca ulaşmadaki performansının istenilen düzeyde olmaması riski olarak adlandırlabilecck olan performans riski, ticari veya teknolojik risk, işbirliği riski gibi kavramlarla da ifade edilmektedir. Bu risk, firmaların çabalarından bağımsız olarak, stratejik amaçlara ulaşılamama riski olarak tanımlanabilir. (Das ve Teng, 1996: 832).

Performans riski, firmalar stratejik işbirliği amaçlanna uygun davransalar bile, performansın istenilen düzeyde gerçekleşememesi olasılığıdır. Hemen belirtilmelidir ki, ar-ge alanında yapılan işbirliğinde göreli olarak performans riski daha yüksek olmaktadır. Bunun dışında uluslararası stratejik işbirliğinin yapıldığı durumlarda da performans riski yüksek olacaktır.

\section{Sonuç}

Ortak stratejik amaçlarını gerçekleştirmek için iki veya daha fazla bağımsız firma tarafından gerçekleştirilen ortaklık anlaşması olarak tanımlanabilecek stratejik işbirliği, firmaların uıgulayabilecekleri stratejiler içinde önemli yer tutmaktadır. Özellikle küresel rekabet koşullarında bu tür stratejiler firmaların faaliyetlerini sürdürebilmesi için çok daha önemli olmaktadır. Stratejik işbirliğini diğer firmalar arası işbirliği türlerinden ayıran en önemli özclliği, firmaların bu işbirliğinde stratejik amaçlarını gerçekleştirme arayışında olmalarıdır. Diğer bir farklılık ise, işbirliği süreci sonunda firmaların hukuki bağımsızlıklarını korumalarıdır. Bu iki farklılık stratejik işbirliğinin özellikleri olarak da tanımlanabilir.

Stratejik işbirliği, günümüzde özellikle çokuluslu firmalar arasında sık bir şekilde gerçekleştirilmektedir. Ancak, sadece çokuluslu firmalar değil ulusal sinırlar içinde faaliyet gösteren firmalar da stratejik işbirliği yoluna gitmektedirler. Çünkü, bu firmalar da küresel rekabet koşullarından 
etkilenmekte ve çoğu zaman yabancı şirketler ile ulusal pazarda rekabet etmek zorunda kalmaktadırlar.

Küresel rekabet koşullarında faaliyetlerini sürdürmek isteyen firmalar açısından stratejik işbirliği bir süreç olarak kabul edilmelidir. Buna göre, süreci oluşturan aşamalar ayn ayn değerlendirilmeli ve her bir aşamanın gerçekleştirilmesi sağlanmalıdır. Süreci oluşturan aşamaların ayn ayn değerlendirilmesi stratejik işbirliği sürecinin başarı ile sonuçlanması açısından önemli olmaktadır.

Firmalar stratejik amaçlanını gerçekleştirmek için bir çok türde işbirliğine gidilebilir. Bu stratejik işbirliği türleri firmaların amaçlarına göre belirlenecektir. Dolayısıyla her stratejik amaç için farkh türde stratejik işbirliği gerçekleştirilebilecektir. Bu açıdan bakıldığında, stratejik işbirliğine başlamadan önce firmaların amaçlarını açık bir şekilde ortaya koymaları, işbirliği faaliyetinin başarı ile sonuçlanmasında önemli katkı sağlayacaktır.

\section{Kaynakça}

BROUTHFRS, Keith D., Lance Fliot Brouthers ve Phil C. HARRIS (1997), "The Five Stages of The Co-operative Venture Strategi Process, Journal of General Management, 97/23:1.

CHAKRAVARTHY Balaji S. ve P'eter I.ORANGE (1991), Managing The Strategy Process: A Framework for a Multibusiness Firm, (New Jersey: I'rentice-l lall International Editions).

ÇFL.IK, Orhan (1999), Şirket Birleşmeleri ve Birleşmelerde Şirket Değerlemesi, (Ankara: Turhan Kitabevi).

DAS T.K. ve Bing Sheng TF.NG (1997), "Sustaining Strategic Alliances: Options and Guidelines", Journal of General Management, 97/22: 4.

DAS T.K. ve Bing Sheng TENG (1996), "Risk Tipes and Interfirm Alliance Structures", Joumal of Management Studies, 96/33:6.

GREEN, Milford B. (1990), Mergers and Aquisitions: Geographical and Spatial Perspective, (New York: Routledge, Inc.).

GRUCA, Thomas S., Deepika NATH ve Ajay MEIHRA (1997), "Fxploiting Sinergy for Competitive Advantage", Long Range Planning, $97 / 30: 4$.

HAMFI., Garı, Yves I.. DOZ ve C.K. PRAHALAD (1989), "Collaborate with Your Competitors and Win, Harvard Business Review, 1989/67:1.

KHEMANI, Syham ve Leonard WAVERMAN" (1997), "Strategic Alliances: A threat to Competition?", Competition Policy in The Global Economy: Modalities for Cooperation, Der.: Leonard Waverman, S. Comarnor ve A. Goto, (London: Routledge, Inc.).

KOCH, Richard (1995), A-Z of Management and Finance, (I London: FT I'itman Publishing). 
KUEMMERLE, Walter (1997), "Building Effective R\&D Capabilities Abroad", Harvard Business Review, 97/84:2.

MANSFIELD, Edward D. (1994), "Alliances and Trade: An Emprical Analysis", Allies, Adversaries and International Trade, Der.: Joanne Gowa, (New Jersel: Princeton Universit Press).

MOORE, James F. (1996), The Death of Competition, (New York: John Wiles \& Sons, Inc.).

MOWERY, David Joanne E. OXLEY ve Brain S. SILVERMAN (1996), "Strategic alliances and Interfirm Knowledge Transfer", Strategic Management Journal, 96/17:Winter-Special Issue.

MURRAY Edwin A. ve John F. MAHON (1993), "Strategic Alliances: Gateway to the New Europe?", Long Range Planning, 93/ 26: 4.

MÜFTÜOǦLU, Tamer (1997), Türkiye'deKüçük ve Orta Ölş̧ekli İşletmeler. Sorunlar, Öneriler, (Ankara: EGS Bank Yayınları No: 1).

NELSON, Carl A. (1994), Managing Globaly, (New York: Irwin Professional Publishing).

NEWMAN Victor ve Kazem CHAHARBAGHI (1996), "Strategic Alliances in Fast-Moving Markets", Long Range Planning, 96/29:6.

SPEKMAN, Robert E., Lynn A. ISABFILLA, Thomas C. MACAVOY ve Thedore FORBES (1996), "Creating Strategic Alliances which Endure", Long Range Planning, 96/29:3.

STAFFORD, Fdwin R. (1994), "Lising Co-operative Strategies to Make Alliance Work", Long Range Planning, 94/27: 3.

WARD, Keith (1995), Corporate Financial Strategy, (London: Butterworth-Heinemann, Inc).

WATIINE, Kenneth Johan ROOS ve Ceorge Von KROCH (1996). 'Towards a Theory of Knowledge Transfer in a Coorerative Context", Managing Knowledge Perspective on Cooperation, Der.: George von Krogh ve Johan Ross, (London: Sage Publications, Inc.). 